\title{
PERENCANAAN DAN PENGEMBANGAN WILAYAH BERBASIS SEKTOR EKONOMI UNGGULAN DI KABUPATEN KERINCI PROVINSI JAMBI
}

\author{
Mery Monica \\ Program Magister Perencanaan Wilayah dan Kota, Fakultas Teknik, Universitas Diponegoro, Semarang, Indonesia
} Email Koresponden: merymonica09@gmail.com

Diterima: 09-12-2020, Revisi: 16-12-2020, Disetujui: 20-12-2020

C)2020 Program Studi Pendidikan Geografi, FISE, Universitas Hamzanwadi

\begin{abstract}
Abstrak Setiap wilayah memiliki potensi sumberdaya yang berbeda, sehingga diperlukan kajian mengenai potensi sumberdaya yang menjadi unggulan dari setiap wilayah, begitu juga dengan Kabupaten Kerinci. Hal ini dilakukan sebagai dasar dalam pembuatan kebijakan pengembangan wilayah yang tepat di Kabupaten Kerinci. Penelitian ini bertujuan untuk menggambarkan pola perubahan dan pertumbuhan sektoral dalam perekonomian, menentukan sektor unggulan, dan melihat perkembangan jumlah penduduk dalam beberapa tahun terakhir, sehingga dapat dijadikan pertimbangan dalam perumusan kebijakan perencanaan pembangunan dalam kerangka pengembangan wilayah. Metode penelitian yang digunakan adalah penelitian kuantitatif dengan menggunakan analisis Location Quotient (LQ), analisis Shift Share dan analisis kependudukan. Hasil penelitian menunjukkan sektor basis yang berpotensi dikembangkan sebagai penunjang ekonomi dan tergolong dalam kriteria sektor maju, tumbuh pesat dan kompratif di Kabupaten Kerinci adalah sektor Informasi dan Komunikasi.
\end{abstract}

Kata kunci: perencanaan, pengembangan wilayah, sektor unggulan, Kabupaten Kerinci

\begin{abstract}
Each region has different potential resources, so it is necessary to study the potential resources that are superior in each region, as well as Kerinci Regency. This is done as a basis for making appropriate regional development policies in Kerinci Regency. This study aims to describe the pattern of sectoral change and growth in the economy, determine the leading sectors, and see the development of the population in recent years, so that it can be taken into consideration in the formulation of development planning policies within the framework of regional development. The research method used is quantitative research using Location Quotient (LQ) analysis, Shift Share analysis and population analysis. The results showed that the basic sector that has the potential to be developed as an economic support and is classified as a developed, fast growing and competitive sector in Kerinci Regency is the Information and Communication sector.
\end{abstract}

Keywords: planning, regional development, leading sector, Kerinci Regency

\section{PENDAHULUAN}

Setelah ditetapkannya Undang-Undang Nomor 22 Tahun 1999 tentang Pemerintahan Daerah, maka sistem otonomi daerah menggantikan sistem sentralistik. Dengan demikian, masing-masing daerah sudah bebas dalam menetapkan sektor yang diprioritaskan pengembangannya. Kemampuan pemerintah daerah dalam melihat sektor yang memiliki keunggulan dan kelemahan pada wilayahnya menjadi semakin penting. Sektor yang unggul memiliki peluang yang lebih baik untuk dikembangkan, sehingga diharapkan dapat mendorong sektor-sektor lain agar lebih berkembang. Potensi daerah satu dengan daerah lainnya pasti berbeda, karena hal ini terkait dengan karakteristik masing-masing daerah. Sehingga upaya untuk mencapai tujuan pembangunan ekonomi daerah dan kebijakan utama yang perlu dilakukan adalah mengusahakan semaksimal mungkin agar prioritas pembangunan daerah sesuai dengan potensi yang dimiliki oleh daerah tersebut. Masalah pokok dalam pembangunan daerah terletak pada penekanan kebijakan pembangunan yang mendasar pada ciri khas daerah yang bersangkutan dengan menggunakan potensi sumberdaya manusia, kelembagaan, dan sumber daya fisik secara lokal. 
Undang-Undang Nomor 32 Tahun 2004 menjelaskan bahwa pembangunan daerah sebagai bagian integral dari pembangunan nasional dilaksanakan oleh pemerintah daerah berdasarkan prinsip otonomi dan pengaturan sumber daya yang diarahkan untuk mempercepat terwujudnya kesejahteraan masyarakat melalui peningkatan pelayanan, pemberdayaan dan partisipasi masyarakat serta peningkatan daya saing daerah. Kebijakan ini telah memberikan keleluasaan bagi daerah untuk menyelenggarakan pemerintahannya di berbagai bidang kehidupan dengan harapan dapat mengoptimalkan berbagai potensi daerah yang belum tergarap baik potensi alam maupun potensi manusia, memutuskan mata rantai pelayanan yang sebelumnya terpusat di satu wilayah, memunculkan pusat-pusat pertumbuhan ekonomi baru dan memicu motivasi masyarakat untuk berpartisipasi aktif dalam pembangunan guna meningkatkan kesejahteraannya. Implikasi yang paling strategis dalam hubungan ini adalah Pemerintah Daerah dituntut untuk mampu membiayai sendiri pembangunan daerahnya. Oleh sebab itu, dalam proses pembangunan daerah perlu diterapkan pengembangan wilayah berbasis potensi unggulan daerah guna membiayai dan mengefektifkan pelaksanaan pembangunan daerah sehingga memiliki daya saing dalam persaingan nasional maupun global. Proses pengembangan wilayah tidak dapat dilakukan serentak pada semua sektor perekonomian, namun diprioritaskan pada pengembangan sektor ekonomi yang memiliki potensi perkembangan cukup besar. Sektor ini diharapkan dapat berkembang dan mendorong sektor ekonomi yang terkait untuk berkembang sehingga tercipta keterkaitan sektoral (Darlen et al., 2015; Ernan et al., 2011).

Pengembangan suatu wilayah harus berdasarkan pengamatan terhadap kondisi internal, sekaligus mengantisipasi perkembangan eksternal. Faktor-faktor internal mencakup pola-pola pengembangan Sumber Daya Manusia (SDM), informasi pasar sumber daya modal dan investasi, kebijakan dalam investasi, pengembangan infrastruktur, pengembangan kemampuan kelembagaan lokal dan kepemerintahan, serta berbagai kerjasama dan kemitraan. Sedangkan faktor eksternal meliputi kesenjangan wilayah dan pengembangan kapasitas otonomi daerah, perdagangan bebas dan otonomi daerah itu sendiri. Sehingga konsep pengembangan wilayah paling tidak didasarkan pada prinsip-prinsip antara lain: 1) berbasis sektor unggulan; 2) dilakukan atas dasar karakteristik daerah; 3) dilakukan secara efisien; dan 4) pengembangan wilayah berbasis pelaku pembangunan. Berdasarkan prinsip-prinsip dalam konsep pengembangan wilayah tersebut maka penentuan sektor unggulan menjadi hal yang sangat penting sebagai dasar perencanaan pembangunan daerah, hal tersebut dikarenakan daerah memiliki kesempatan dan wewenang untuk membuat strategi kebijakan yang sesuai dengan potensi daerah agar dapat mempercepat pembangunan daerah untuk meningkatkan kesejahteraan masyarakat (Siska et al., 2015).

Mujahid \& Marsoyo (2019) menyimpulkan bahwa pembangunan wilayah sebagaimana yang diupayakan pemerintah daerah dan seluruh masyarakat mensyaratkan terjadinya pertumbuhan ekonomi melalui peningkatan pendapatan masyarakat yang dapat dihasilkan melalui proses akumulasi investasi terhadap modal produksi yang dimiliki masyarakat. Selanjutnya, Setianto \& Susilowati (2014) menjelaskan bahwa pendekatan pembangunan wilayah dapat dilakukan berdasarkan potensinya. Kebijakan pembangunan terkait dengan pengembangan wilayah tidak dapat dilihat secara umum tanpa melihat potensi keragaman komoditas, namun harus spesifik wilayah supaya program tersebut dapat dilaksanakan dengan baik, tepat sasaran dan nyata. Perencanaan pembangunan dimulai dengan menganalisis kondisi wilayah, potensi unggulan wilayah dan permasalahan yang ada di wilayah tersebut yang selanjutnya dapat digunakan sebagai dasar pertimbangan dalam menentukan strategi pengembangan wilayah.

Mendukung hal tersebut di atas, Kurniawan (2016) menyatakan bahwa pertumbuhan ekonomi juga mempunyai pengertian suatu proses jangka panjang (bukan suatu gambaran ekonomi sesaat) perubahan output per kapita, dari waktu kewaktu, dalam hal ini terkait dengan perkembangan jumlah output total (GNP) dan jumlah penduduk. Suatu pertumbuhan ekonomi tumbuh apabila dalam jangka waktu yang cukup lama mengalami kenaikan output per kapita. Laju pertumbuhan ekonomi akan diukur melalui indikator-indikator perkembangan PDRB dari tahun ke tahun. Pertumbuhan ekonomi juga dapat diartikan sebagai kenaikan PDRB, tanpa memandang apakah kenaikan itu lebih besar atau lebih kecil dari pertumbuhan penduduk atau apakah perubahan struktur ekonomi berlaku atau tidak. Pada tingkat daerah, pertumbuhan ekonomi pada dasarnya membahas tentang hal mengapa suatu 
daerah dapat tumbuh cepat dibandingkan dengan perekonomian pada wilayah yang lebih luas, sedangkan yang lainnya kurang berkembang. Maka melanjutkan pernyataan tersebut, Isyanto et al., (2018) mengatakan setiap wilayah memiliki potensi sumberdaya yang berbeda, sehingga diperlukan suatu kajian mengenai potensi sumberdaya yang menjadi unggulan dari setiap wilayah tersebut sebagai dasar dalam pembuatan kebijakan pengembangan wilayah yang tepat sebagai salah satu kebijakan pembangunan ekonomi wilayah adalah pengembangan kawasan andalan berbasis potensi wilayah tersebut.

Terdapat beberapa penelitian terkait perencanaan dan pengembangan wilayah berbasis sektor ekonomi unggulan, terutama dengan fokus kajian yang cukup beragam. Kartikaningdyah (2012) membatasi penelitiannnya pada sektor basis dan non basis Kabupaten Lingga Kepulauan Riau, sebagaimana juga penelitian yang dilakukan oleh Jumiyanti (2018) yang juga membatasi penelitiannnya pada sektor basis dan non basis di Kabupaten Gorontalo. Selanjutnya Setianto \& Susilowati (2014) membatasi penelitiannya pada sektor unggulan yang dapat dikembangkan lebih lanjut dengan melihat tingkat kesesuaian lahan di Kabupaten Banjarnegara. Sedangkan Isyanto et al., (2018) membatasi penelitiannya pada daerah-daerah di Kabupaten Ciamis yang merupakan daerah basis untuk komoditas ternak sapi potong, domba, kambing, ayam buras, ayam ras petelur, ayam ras pedaging dan itik. Sementara itu Darlen et al., (2015) melakukan penelitan mengenai sektor-sektor unggulan yang mampu meningkatkan perekonomian di Kabupaten Manggarai Timur Provinsi NTT dan melihat kawasan yang tidak sesuai peruntukannya berdasarkan kemampuan lahan. Begitu pula dengan Wahyudi et al., (2014) yang membatasi penelitannya pada sektor unggulan yang mempunyai tingkat kompetitif lebih besar, derajat desentralisasi fiskal, serta langkah strategis yang harus dilakukan oleh pemerintah Kabupaten Pasaman dalam mengelola keuangan daerahnya. Selanjutnya Siska et al., (2015) melakukan penelitan terkait dengan strategi peningkatan sarana prasarana yang dapat memperlancar konektivitas antar wilayah di Kawasan Andalan Kandangan Kalimantan Selatan dan pemerintah sebagai aktor utama pengembangan agroindustri. Sedangkan Kurniawan (2016) melakukan penelitian mengenai sektor basis dan non basis serta sektor yang prospektif untuk dikembangkan lebih lanjut dalam upaya meningkatkan dan mendorong perekonomian daerah Kabupaten kerinci Provisi Jambi.

Berdasarkan uraian beberapa penelitian sebelumnya, maka terlihat jelas celah kosong yang harus diisi untuk memunculkan kebaruan penelitian ini khususnya pada pola perubahan dan pertumbuhan sektoral dalam perekonomian, sektor basis yang berpotensi untuk dikembangkan sebagai penunjang ekonomi wilayah dengan kriteria tergolong ke dalam sektor yang maju dan tumbuh dengan pesat, sektor basis dan kompratif sehingga dapat dijadikan pertimbangan dalam perumusan kebijakan dan perencanaan pembangunan dalam kerangka pengembangan wilayah di Kabupaten Kerinci Provinsi Jambi. Hal ini juga bertujuan untuk merancang strategi pengembangan wilayah yang tepat dan menciptakan investasi yang kondusif untuk menarik minat para investor ke Kabupaten Kerinci. Sehingga peneliti memastikan bahwa penelitian ini akan memiliki perbedaan dan kebaruan dengan penelitian terkait yang sudah ada dan dapat memberikan sumbangsih bagi pengembangan ilmu pengatahuan. Berdasarkan latar belakang tersebut, maka penelitian ini bertujuan untuk menggambarkan pola perubahan dan pertumbuhan sektoral dalam perekonomian, menentukan sektor unggulan, dan melihat perkembangan jumlah penduduk dalam bebrapa tahun terakhir, sehingga dapat dijadikan pertimbangan dalam perumusan kebijakan dan perencanaan pembangunan dalam kerangka pengembangan wilayah di Kabupaten Kerinci Provinsi Jambi kedepannya.

\section{METODE PENELITIAN}

Metode penelitian yang digunakan dalam penelitian ini adalah metode penelitian kuantitatif dengan analisis data sekunder. Data sekunder diperoleh dari instansi terkait dan kemudian data tersebut dijelaskan secara deskriptif kuantitatif. Penelitian ini melihat sektor ekonomi unggulan dan pergeserannya di Kabupaten Kerinci. Selanjutnya dilakukan kajian pustaka yang bersumber dari jurnal ilmiah dan buku sebagai referensi yang terkait dengan penelitian ini. Lokasi penelitian ini adalah di Kabupaten Kerinci, Provinsi Jambi. Batas administrasi Kabupaten Kerinci lebih jelasnya dapat dilihat pada gambar 1. 


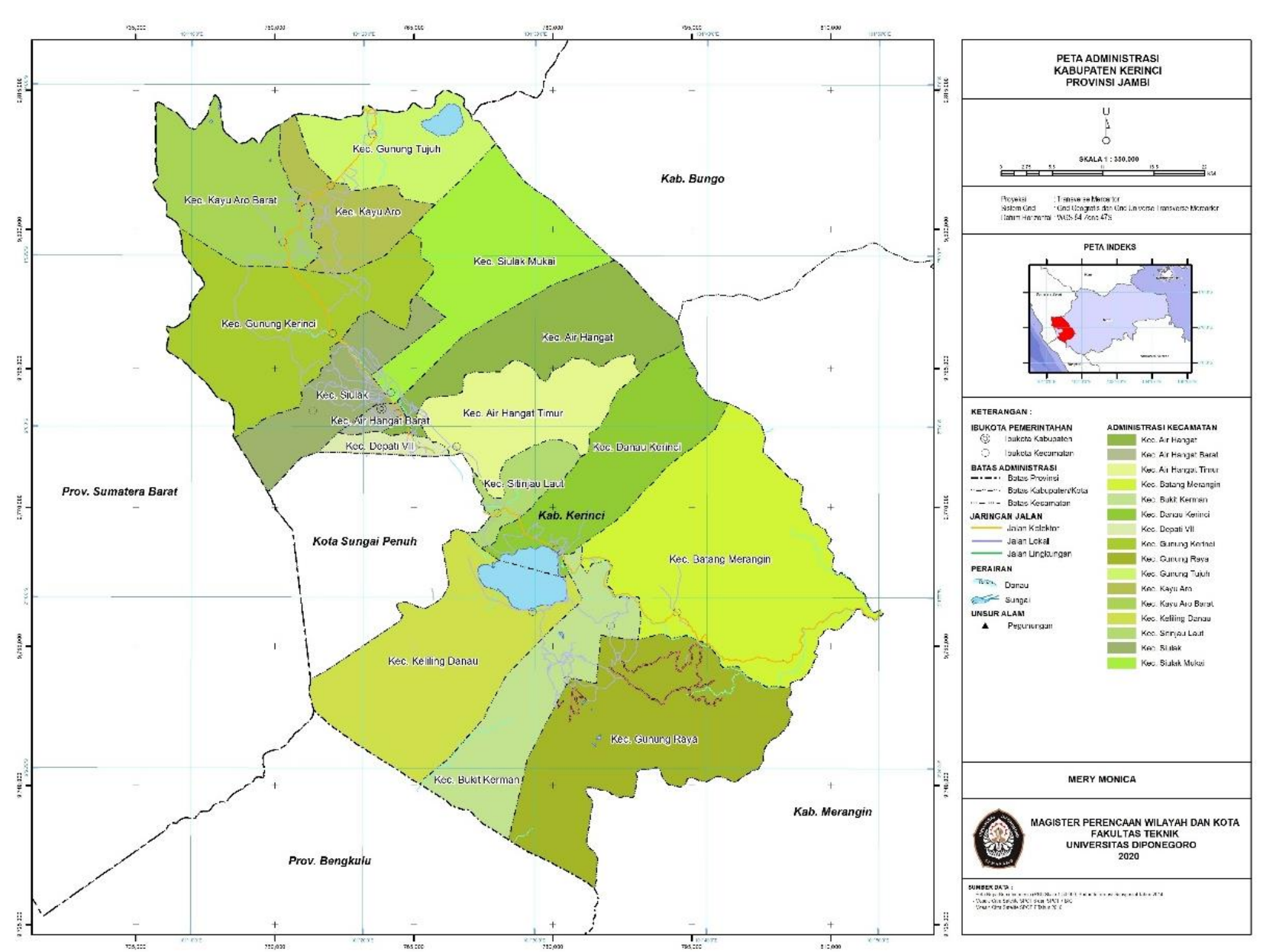

Gambar 1. Batas Administrasi Kabupaten Kerinci

(Sumber : Peneliti, 2020)

Jenis dan sumber data dalam penelitian ini adalah data sekunder yang disajikan dalam bentuk tahunan. Adapun data yang dikumpulkan adalah: 1) Produk Domestik Regional Bruto (PDRB) Kabupaten Kerinci tahun 2016 dan 2018 menurut lapangan usaha atas harga berlaku; 2) Produk Domestik Regional Bruto (PDRB) Provinsi Jambi tahun 2016 dan 2018 menurut lapangan usaha atas harga berlaku; 3) Jumlah penduduk Kabupaten Kerinci dari tahun 2014-2018. Setelah data diperoleh dan ditabulasikan sesuai dengan tujuan, maka langkah selanjutnya adalah menganalisis data secara deskriptif dan kuantitatif menggunakan model: 1) Analisis Location Quotient (LQ); 2) Analisis Shift Share; 3) Analisis Kependudukan.

\section{Analisis Location Quotient (LQ)}

Analisis Location Quotient (LQ) merupakan suatu analisis yang digunakan untuk mengetahui sejauh mana tingkat spesialisasi sektor-sektor ekonomi di suatu wilayah yang memanfaatkan sektor basis atau leading sektor. Location Quotient menghitung perbandingan share output sektor i di kota atau kabupaten dan share output sektor i di provinsi. Sektor unggulan berarti sektor bisnis yang tidak akan habis apabila dieksploitasi oleh pemerintah wilayah (Jumiyanti, 2018). Apabila hasil perhitungannya menunjukkan LQ $>1$, berarti merupakan sektor basis dan sedangkan LQ $<1$, berarti bukan sektor basis. Teknik ini memiliki asumsi bahwa semua penduduk di suatu daerah mempunyai pola permintaan yang sama dengan pola permintaan nasional (regional) (Kartikaningdyah, 2012).

Untuk menentukan sektor basis dan non basis di Kabupaten Kerinci digunakan metode analisis Location Quotient (LQ). Metode LQ merupakan salah satu pendekatan yang umum digunakan dalam model ekonomi basis sebagai langkah awal untuk memahami sektor kegiatan dari PDRB Kabupaten Kerinci yang menjadi pemacu pertumbuhan. Metode LQ digunakan untuk mengkaji kondisi perekonomian, mengarah pada identifikasi spesialisasi kegiatan perekonomian. Sehingga nilai LQ yang 
sering digunakan untuk penentuan sektor basis dapat dikatakan sebagai sektor yang akan mendorong tumbuhnya atau berkembangnya sektor lain serta berdampak pada penciptaan lapangan kerja.

LQ adalah indikator sederhana yang menunjukkan kekuatan atau besar kecilnya peranan suatu sektor dalam suatu daerah dibandingkan dengan daerah diatasnya. Ada dua cara untuk mengukur LQ, yaitu melalui pendekatan nilai tambah atau PDRB dan pendekatan tenaga kerja. Berkaitan dengan tujuan penelitian, dalam mengukur LQ menggunakan pendekatan nilai tambah atau PDRB adalah sebagai berikut :

$$
\text { Rumus } \mathbf{L Q}=\frac{\mathbf{p s} / \mathbf{p l}}{\mathbf{P s} / \mathbf{P I}}
$$

Sumber: Kesuma \& Utama (2015), dimodifikasi.

Keterangan :

- $\mathrm{LQ}=$ Location Quotient

- ps = Produksi/kesempatan kerja sektor $\mathrm{i}$, pada tingkat lokal

- $\mathrm{pl}=$ Produksi/kesempatan kerja total, pada tingkat lokal

- Ps $=$ Produksi/kesempatan kerja sektor i, pada tingkal regional

- $\mathrm{Pl}=$ Produksi/kesempatan kerja total, pada tingkal regional

Hasil perhitungan formulasi di atas kemudian dapat dimasukkan dalam kategori berikut:

$\mathrm{LQ} \geq 1=$ sektor basis

$\mathrm{LQ}<1=$ sektor non-basis

\section{Analisis Shift Share}

Shift Share Analysis merupakan salah satu dari sekian banyak teknik analisis untuk memahami pergeseran struktur aktifitas di suatu lokasi tertentu dibandingkan dengan suatu referensi (dengan cakupan wilayah yang lebih luas) dalam dua titik waktu. Pemahaman struktur aktifitas dari hasil analisis Shift-Share menjelaskan kemampuan berkompetisi (competitiveness) aktifitas tertentu disuatu wilayah secara dinamis atau perubahan aktivitas dalam cakupan lebih luas. Hasil analisis Shift-Share mampu memberikan gambaran sebab-sebab terjadinya pertumbuhan suatu aktifitas di suatu wilayah. Sebab sebab yang dimaksud dibagi menjadi tiga bagian yaitu: 1) sebab yang berasal dari dinamika lokal (subwilayah); 2) sebab dari dinamika aktifitas/sektor (total wilayah); dan 3) sebab dari dinamika wilayah secara umum (laju pertumbuhan agregat) (Wahyudi et al., 2014). Untuk dapat mengidentifikasi keunggulan daerahnya dan menganalisis industri atau kategori yang menjadi dasar perekonomian daerah maka digunakan teknik analisis shift share. Analisis shift share juga merupakan suatu analisis yang dilakukan untuk mengetahui perubahan kegiatan ekonomi, misalnya: produksi dan kesempatan kerja pada periode waktu tertentu ( $>1$ tahun). Hasil analisis shift share ini digunakan untuk mengetahui bagaimana perkembangan suatu sektor di suatu daerah/wilayah dibandingkan secara relatif dengan sektor lainnya, apakah tumbuh cepat atau lambat.

Dalam analisis ini diasumsikan bahwa perubahan produksi/kesempatan kerja dipengaruhi oleh 3 komponen pertumbuhan wilayah, yaitu: 1) Komponen Pertumbuhan Nasional (KPN) yang merupakan komponen share dan sering disebut sebagai national share, KPN adalah perubahan produksi atau kesempatan kerja suatu wilayah yg disebabkan oleh perubahan produksi atau kesempatan kerja secara umum, kebijakan ekonomi nasional dan kebijakan lain yang mampu mempengaruhi sektor perekonomian dalam suatu wilayah; 2) Komponen Pertumbuhan Proporsional (KPP) yang merupakan komponen proportional shift, yaitu penyimpangan (deviation) dari national share dalam pertumbuhan wilayah. KPP adalah perubahan produksi atau kesempatan kerja suatu wilayah yang disebabkan oleh komposisi sektor-sektor industri di wilayah tersebut, perbedaan sektor dalam permintaan produk akhir, serta perbedaan dalam struktur dan keragaman pasar. KPP bernilai positif (KPP >0) pada wilayah/ daerah yang berspesialisasi dalam sektor yg secara nasional tumbuh cepat. KPP bernilai negatif $(\mathrm{KPP}<0)$ pada wilayah/daerah yang berspesialisasi dalam sektor yg secara nasional tumbuh lambat; 3) Komponen Pertumbuhan Pangsa Wilayah (KPPW) yang merupakan komponen differential shift, sering disebut komponen lokasional atau regional atau sisa lebihan. KPPW adalah perubahan produksi atau kesempatan kerja suatu wilayah yang disebabkan oleh keunggulan komparatif wilayah tersebut, 
dukungan kelembagaan, prasarana sosial ekonomi serta kebijakan lokal di wilayah tersebut. KPPW bernilai positif (KPPW > 0) pada sektor yang mempunyai keunggulan komparatif/ keuntungan lokasional di wilayah/daerah tersebut. KPPW bernilai negatif $(\mathrm{KPPW}<0)$ pada sektor yang tidak mempunyai keunggulan komparatif / tidak dapat bersaing.

Rumus

$$
\begin{aligned}
\mathrm{PE}= & \mathrm{KPN}+\mathrm{KPP}+\mathrm{KPPW} \\
& =(\mathrm{Yt} / \mathrm{Yo}-1)+(\mathrm{Yit} / \mathrm{Yio}-\mathrm{Yt} / \mathrm{Yo})+(\mathrm{yit} / \text { yio }-\mathrm{Yt} / \mathrm{Yo}) \\
& =[\mathrm{Ra}-1]+[\mathbf{R i}-\mathrm{Ra}]+[\mathrm{ri}-\mathrm{Ra}]
\end{aligned}
$$

Sumber: Negara \& Putri (2020), dimodifikasi.

Keterangan :

- $\mathrm{Yt}=$ indikator ekonomi wilayah Nasional, akhir tahun analisis

- Yo = indikator ekonomi wilayah Nasional, awal tahun analisis

- Yit $=$ indikator ekonomi wilayah Nasional sektor $\mathrm{i}$, akhir tahun analisis

- Yio = indikator ekonomi wilayah Nasional sektor $\mathrm{i}$, awal tahun analisis

- yit $=$ indikator ekonomi wilayah Lokal sektor i, akhir tahun analisis

- yio $=$ indikator ekonomi wilayah Lokal sektor $i$, awal tahun analisis

Ketentuan : PS $=\mathrm{KPP}+\mathrm{KPPW}$

- Jika PS $\geq 0=$ sektor tersebut progresif/maju.

- Jika PS $<0$ = sektor tersebut lamban / mundur.

\section{Analisis Kependudukan}

Analisis penduduk berkaitan dengan usaha untuk mengidentifikasi karakteristik dan dinamika penduduk, yang meliputi: 1) besaran jumlah penduduk dan pertumbuhannya; 2) sebaran penduduk; 3) faktor yang mempengaruhi perubahan jumlah penduduk; dan 4) struktur penduduk. Analisis kependudukan perlu memperhatikan karakteristik penduduk masa lalu, masa sekarang dan masa depan sebagai landasan dalam melakukan perencanaan wilayah/kota. Analisis jumlah dan pertumbuhan penduduk didasarkan dari kecenderungan pertambahan atau pengurangan per satuan waktu amatan.

\section{TEMUAN DAN PEMBAHASAN}

Pertumbuhan Produk Domestik Regional Bruto (PDRB) di Kabupaten Kerinci dapat dilihat pada tabel 1 dibawah ini:

Tabel 1 Produk Domestik Regional Bruto Kabupaten Kerinci Atas Dasar Harga Berlaku Menurut Lapangan Usaha (Juta Rupiah)

\begin{tabular}{clll}
\hline \multirow{2}{*}{ Kategori } & \multicolumn{1}{c}{$\begin{array}{c}\text { Lapangan Usaha } \\
\text { (Sektor) }\end{array}$} & \multicolumn{1}{c}{ PDRB Kabupaten Kerinci } \\
\cline { 3 - 4 } A & Pertanian, Kehutanan, dan Perikanan & $4,269,999.43$ & \multicolumn{1}{c}{ PDRB 2018 } \\
\hline B & Pertambangan dan Penggalian & $117,464.17$ \\
C & Industri Pengolahan/Manufacturing & $225,733.58$ & $127,692.13$ \\
D & Pengadaan Listrik dan Gas & $2,786.34$ & $272,227.47$ \\
E & Pengadaan Air, Pengelolaan Sampah, Limbah dan & $28,970.29$ & $34,127.8$ \\
& Daur Ulang & & \\
F & Konstruksi & $458,301.59$ & $532,658.16$ \\
G & Perdagangan Besar dan Eceran; Reparasi Mobil dan & $859,931.02$ & $1,096,589.56$ \\
& Sepeda Motor & & \\
H & Transportasi dan Pergudangan & $180,748.04$ & $209,699.01$ \\
I & Penyediaan Akomodasi dan Makan Minum & $69,475.22$ & $81,472.48$ \\
J & Informasi dan Komunikasi & $505,061.66$ & $674,444.75$ \\
K & Jasa Keuangan dan Asuransi & $83,284.9$ & $98,002.98$ \\
L & Real Estat & $139,567.67$ & 168145.51 \\
M,N & Jasa Perusahaan & $3,614.11$ & $4,474.44$ \\
O & Administrasi Pemerintahan, Pertahanan dan Jaminan & $550,215.2$ & $678,891.44$
\end{tabular}




\begin{tabular}{|c|c|c|c|}
\hline \multirow{2}{*}{ Kategori } & \multirow{2}{*}{$\begin{array}{c}\text { Lapangan Usaha } \\
\text { (Sektor) }\end{array}$} & \multicolumn{2}{|c|}{ PDRB Kabupaten Kerinci } \\
\hline & & PDRB 2016 & PDRB 2018 \\
\hline $\mathrm{P}$ & Jasa Pendidikan & $333,639.06$ & $415,285.15$ \\
\hline Q & Jasa Kesehatan dan Kegiatan Sosial & $110,047.81$ & $136,167.11$ \\
\hline R,S,T,U & Jasa lainnya & $114,262.06$ & $139,952.11$ \\
\hline & Total & $8,052,841.08$ & $9,546,774.35$ \\
\hline
\end{tabular}

Sumber : Produk Domestik Regional Bruto Kabupaten Kerinci Menurut Lapangan Usaha 2014 - 2018

Berdasarkan tabel 1 dapat diketahui bahwa pertumbuhan PDRB di Kabupaten Kerinci tahun 2016 ke tahun 2018 terjadi perkembangan, secara umum setiap sektoral mengalami peningkatan kontribusi terhadap PDRB. Semakin besar sumbangan atau peran suatu sektor ekonomi dalam pembentukan PDRB, maka semakin besar pula pengaruh sektor tersebut dalam perkembangan perekonomian suatu daerah. Dari tahun 2016 sampai tahun 2018 sektor Pertanian, Kehutanan, dan Perikanan memiliki kontribusi cukup besar jika dibandingkan dengan sektor lain, sebesar Rp. 4,269,999.43 pada tahun 2018, dan merupakan sektor yang memberikan kontribusi terbesar terhadap PDRB Kabupaten Kerinci. Selanjutnya sektor Perdagangan Besar dan Eceran; Reparasi Mobil dan Sepeda Motor yang memberikan kontribusi terbesar kedua sebesar Rp. 1,096,589.56 pada tahun 2018, kemudian diikuti oleh sektor Administrasi Pemerintahan, Pertahanan dan Jaminan Sosial sebesar Rp. 678,891.44 pada tahun 2018.

\section{Analisis sektor basis pertumbuhan ekonomi Kabupaten Kerinci}

Analisis Location Quotient (LQ) digunakan untuk mengetahui sektor-sektor ekonomi dalam PDRB yang dapat digolongkan ke dalam sektor basis dan non basis. Hasil perhitungan analisis LQ disajikan pada tabel 2.

Tabel 2. Hasil perhitungan Location Quotient (LQ) Kabupaten Kerinci Tahun 2016 dan 2018

\begin{tabular}{|c|c|c|c|c|}
\hline \multirow{2}{*}{ Kategori } & \multirow{2}{*}{$\begin{array}{l}\text { Lapangan Usaha } \\
\text { (Sektor) }\end{array}$} & \multicolumn{2}{|c|}{ LQ Kabupaten Kerinci } & \multirow{2}{*}{ Keterangar } \\
\hline & & Tahun 2016 & Tahun 2018 & \\
\hline A & Pertanian, Kehutanan, dan Perikanan & 1.7647 & 1.8515 & Basis \\
\hline $\mathrm{B}$ & Pertambangan dan Penggalian & 0.0874 & 0.0663 & Non Basis \\
\hline $\mathrm{C}$ & Industri Pengolahan/Manufacturing & 0.2659 & 0.2859 & Non Basis \\
\hline $\mathrm{D}$ & Pengadaan Listrik dan Gas & 0.5721 & 0.5706 & Non Basis \\
\hline $\mathrm{E}$ & $\begin{array}{l}\text { Pengadaan Air, Pengelolaan Sampah, } \\
\text { Limbah dan Daur Ulang }\end{array}$ & 2.4927 & 2.6335 & Basis \\
\hline $\mathrm{F}$ & Konstruksi & 0.8075 & 0.7892 & Non Basis \\
\hline G & $\begin{array}{l}\text { Perdagangan Besar dan Eceran; } \\
\text { Reparasi Mobil dan Sepeda Motor }\end{array}$ & 0.9016 & 0.9763 & Non Basis \\
\hline $\mathrm{H}$ & Transportasi dan Pergudangan & 0.6686 & 0.6885 & Non Basis \\
\hline I & $\begin{array}{l}\text { Penyediaan Akomodasi dan Makan } \\
\text { Minum }\end{array}$ & 0.7265 & 0.7161 & Non Basis \\
\hline $\mathrm{J}$ & Informasi dan Komunikasi & 1.7177 & 1.8659 & Basis \\
\hline K & Jasa Keuangan dan Asuransi & 0.4090 & 0.4425 & Non Basis \\
\hline $\mathrm{L}$ & Real Estat & 1.0869 & 1.1387 & Basis \\
\hline $\mathrm{M}, \mathrm{N}$ & Jasa Perusahaan & 0.0371 & 0.0392 & Non Basis \\
\hline $\mathrm{O}$ & $\begin{array}{l}\text { Administrasi Pemerintahan, } \\
\text { Pertahanan dan Jaminan Sosial }\end{array}$ & 1.4467 & 1.5455 & Basis \\
\hline $\mathrm{P}$ & Jasa Pendidikan & 1.2384 & 1.2995 & Basis \\
\hline Q & Jasa Kesehatan dan Kegiatan Sosial & 1.2387 & 1.2801 & Basis \\
\hline R,S,T,U & Jasa lainnya & 1.4641 & 1.5311 & Basis \\
\hline
\end{tabular}

Sumber : Hasil Analisis, 2020

Dari tabel 2 dapat diketahui bahwa terdapat 7 sektor yang memiliki nilai lebih dari 1 (LQ $>1$ ) pada tahun 2018, yang pertama adalah Sektor Pengadaan Air, Pengelolaan Sampah, Limbah dan Daur Ulang yang mempunyai potensi sangat besar untuk dikembangkan lebih lanjut yaitu dengan nilai LQ sebesar 2.6335. Sektor kedua yang juga merupakan sektor basis yang memeliki potensi besar dikembangkan adalah sektor Informasi dan Komunikasi dengan nilai LQ sebesar 1.8659. Ketiga adalah sektor pertaniaan, kehutanan, dan perikanan, yaitu sebesar 1.8515 yang merupakan sektor yang menjadi titik tumpuan dalam penyerapan tenaga kerja dan perekonomian di Kabupaten Kerinci. Sektor Administrasi Pemerintahan, Pertahanan dan Jaminan Sosial sebesar 1.5455. Sektor Jasa lainnya yaitu 
sebesar 1.5311, sektor Jasa Kesehatan dan Kegiatan Sosial yaitu 1.2801. Sektor Real Estat 1.1387. Ketujuh sektor tersebut merupakan sektor basis yang dapat meningkatkan laju pertumbuhan ekonomi di Kabupaten Kerinci dan dapat memenuhi kebutuhan di luar Kabupaten Kerinci.

\section{Analisis sektor potensial ekonomi wilayah Kabupaten Kerinci}

Analisis Shift-Share mengasumsikan bahwa perubahan pendapatan (PDRB) suatu wilayah dapat dibagi dalam tiga yaitu: Komponen Pertumbuhan Nasional (KPN), Komponen Pertumbuhan Proporsional (KPP), Komponen Pertumbuhan Pangsa Wilayah (KPPW). Pengaruh Pertumbuhan Provinsi, Nilai KPN positif memiliki makna bahwa sektor diwilayah Kabupaten Kabupaten Kerinci tersebut tumbuh lebih cepat dibandingkan dengan pertumbuhan wilayah Provinsi Jambi, sedangkan yang benilai negatif mengindikasikan bahwa pertumbuhan di Kabupaten Kerinci lebih lambat dibandingkan pertumbuhan diwilayah Provinsi Jambi. Komponen Pertumbuhan Proporsional, Nilai KPP positif bermakna bahwa sektor di Kabupaten Kerinci tersebut merupakan sektor yang maju, sebaliknya apabila bernilai negatif berarti sektor tersebut belum maju. Komponen Pertumbuhan Pangsa Wilayah, Nilai KPPW positif menunjukkan bahwa sektor di wilayah Kabupaten Kerinci memiliki daya saing dibandingkan dengan sektor di wilayah di Provinsi Jambi, sebaliknya apabila bernilai negatif berarti sektor tersebut tidak memiliki daya saing. Hasil analisis tentang sektor unggulan dan potensial untuk menunjang pertumbuhan wilayah Kabupaten Kerinci dicantumkan pada Tabel 3.

Tabel 3. Hasil perhitungan analisis shift share sektor unggulan di Kabupaten Kerinci Tahun 2016 dan 2018

\begin{tabular}{|c|c|c|c|c|c|}
\hline Kategori & $\begin{array}{l}\text { Lapangan Usaha } \\
\text { (Sektor) }\end{array}$ & $\begin{array}{c}\text { Komponen } \\
\text { Pertumbuhan } \\
\text { Nasional } \\
\text { (KPN) }\end{array}$ & $\begin{array}{l}\text { Komponen } \\
\text { Pertumbuhan } \\
\text { Proporsional } \\
\text { (KPP) }\end{array}$ & $\begin{array}{c}\text { Komponen } \\
\text { Pertumbuhan } \\
\text { Pangsa } \\
\text { Wilayah } \\
\text { (KPPW) }\end{array}$ & $\begin{array}{l}\text { Proportional } \\
\text { Shift } \\
\text { (PS) }\end{array}$ \\
\hline $\mathrm{A}$ & $\begin{array}{l}\text { Pertanian, Kehutanan, dan } \\
\text { Perikanan }\end{array}$ & 0.2172 & -0.1003 & -0.0758 & -0.1762 \\
\hline B & $\begin{array}{l}\text { Pertambangan dan } \\
\text { Penggalian }\end{array}$ & 0.2172 & 0.2579 & -0.1277 & 0.1302 \\
\hline $\mathrm{C}$ & $\begin{array}{l}\text { Industri } \\
\text { Pengolahan/Manufacturing }\end{array}$ & 0.2172 & -0.0657 & -0.0112 & -0.0769 \\
\hline $\mathrm{D}$ & Pengadaan Listrik dan Gas & 0.2172 & 0.0685 & 0.0318 & 0.1003 \\
\hline $\mathrm{E}$ & $\begin{array}{l}\text { Pengadaan Air, Pengelolaan } \\
\text { Sampah, Limbah dan Daur } \\
\text { Ulang }\end{array}$ & 0.2172 & -0.0724 & -0.0391 & -0.1115 \\
\hline $\mathrm{F}$ & Konstruksi & 0.2172 & 0.0039 & -0.0549 & -0.0511 \\
\hline G & $\begin{array}{l}\text { Perdagangan Besar dan } \\
\text { Eceran; Reparasi Mobil dan } \\
\text { Sepeda Motor }\end{array}$ & 0.2172 & -0.0080 & 0.0580 & 0.0500 \\
\hline $\mathrm{H}$ & $\begin{array}{l}\text { Transportasi dan } \\
\text { Pergudangan }\end{array}$ & 0.2172 & -0.0605 & -0.0570 & -0.1175 \\
\hline I & $\begin{array}{l}\text { Penyediaan Akomodasi dan } \\
\text { Makan Minum }\end{array}$ & 0.2172 & 0.0043 & -0.0445 & -0.0402 \\
\hline $\mathrm{J}$ & Informasi dan Komunikasi & 0.2172 & 0.0450 & 0.1182 & 0.1632 \\
\hline $\mathrm{K}$ & $\begin{array}{l}\text { Jasa Keuangan dan } \\
\text { Asuransi }\end{array}$ & 0.2172 & -0.1005 & -0.0404 & -0.1409 \\
\hline $\mathrm{L}$ & Real Estat & 0.2172 & -0.0365 & -0.0124 & -0.0489 \\
\hline $\mathrm{M}, \mathrm{N}$ & Jasa Perusahaan & 0.2172 & -0.0160 & 0.0209 & 0.0048 \\
\hline $\mathrm{O}$ & $\begin{array}{l}\text { Administrasi Pemerintahan, } \\
\text { Pertahanan dan Jaminan } \\
\text { Sosial }\end{array}$ & 0.2172 & -0.0313 & 0.0167 & -0.0146 \\
\hline $\mathrm{P}$ & Jasa Pendidikan & 0.2172 & 0.0007 & 0.0275 & 0.0282 \\
\hline Q & $\begin{array}{l}\text { Jasa Kesehatan dan } \\
\text { Kegiatan Sosial }\end{array}$ & 0.2172 & 0.0121 & 0.0202 & 0.0323 \\
\hline $\mathrm{R}, \mathrm{S}, \mathrm{T}, \mathrm{U}$ & $\begin{array}{l}\text { Jasa lainnya } \\
\text { Total }\end{array}$ & $\begin{array}{l}0.2172 \\
\mathbf{0 . 2 1 7 2}\end{array}$ & $\begin{array}{l}-0.0147 \\
\mathbf{0 . 0 0 0 0}\end{array}$ & $\begin{array}{l}0.0077 \\
\mathbf{- 0 . 0 3 1 7}\end{array}$ & $\begin{array}{l}-0.0070 \\
-\mathbf{0 . 0 3 1 7}\end{array}$ \\
\hline
\end{tabular}

Sumber : Hasil Analisis, 2020. 
Berdasarkan hasil analisis sektor unggulan dan potensial untuk menunjang pertumbuhan wilayah Kabupaten Kerinci, maka selanjutnya dilakukan Plotting. Untuk lebih jelasnya dapat dilihat pada gambar 2.

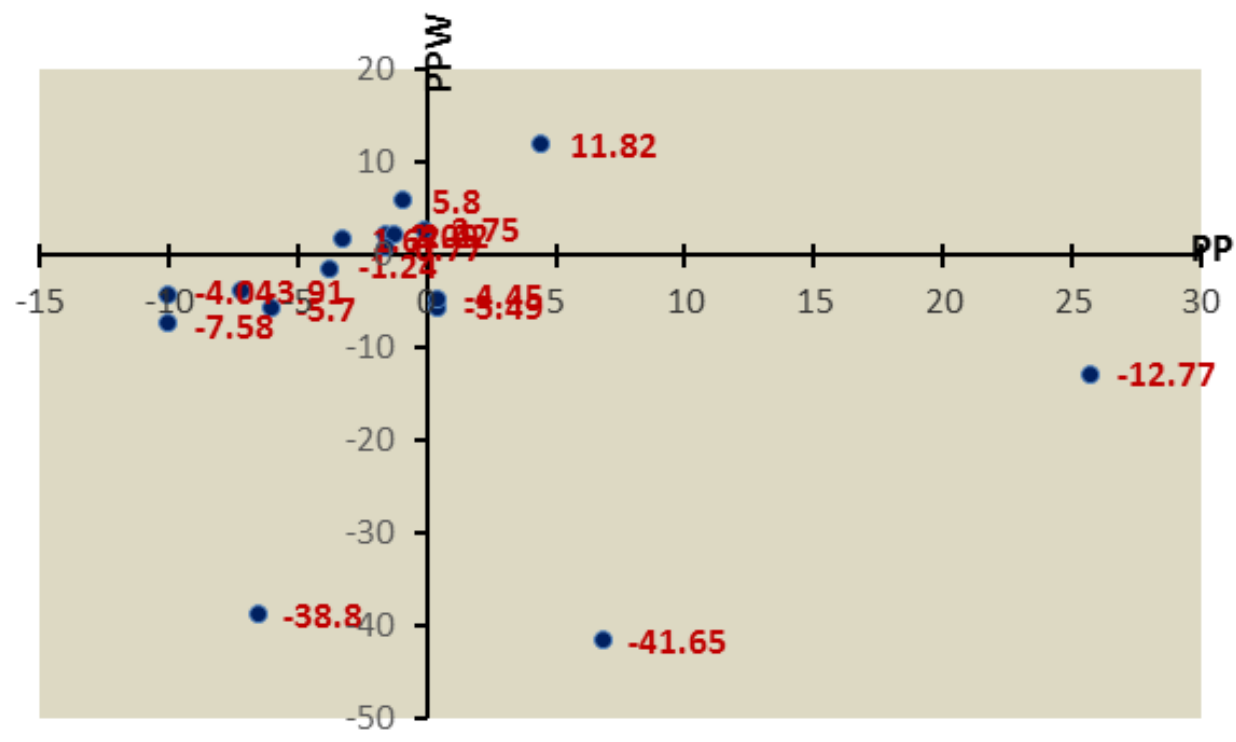

Gambar 2. Hasil Plotting PP - PPW

(Sumber : Hasil Analisis, 2020)

\section{Gabungan hasil Analisis LQ dan Shift Share}

Hasil analisis sektor basis (LQ) dan analisis sektor potensial (shift-share) dapat dilihat pada tabel 4.

Tabel 4. Hasil Analisis LQ dan Shift-Share

\begin{tabular}{|c|c|c|c|c|c|}
\hline \multirow{2}{*}{ Kategori } & \multirow{2}{*}{$\begin{array}{l}\text { Lapangan Usaha } \\
\text { (Sektor) }\end{array}$} & \multirow{2}{*}{ LQ } & \multicolumn{3}{|c|}{ Shift Share } \\
\hline & & & KPP & KPPW & PS \\
\hline $\mathrm{A}$ & $\begin{array}{l}\text { Pertanian, Kehutanan, dan } \\
\text { Perikanan }\end{array}$ & Basis & $\begin{array}{l}\text { Tumbuh } \\
\text { lambat }\end{array}$ & $\begin{array}{l}\text { Tidak } \\
\text { Komparatif }\end{array}$ & Mundur \\
\hline $\mathrm{B}$ & Pertambangan dan Penggalian & Non Basis & $\begin{array}{l}\text { Tumbuh } \\
\text { cepat }\end{array}$ & $\begin{array}{l}\text { Tidak } \\
\text { Komparatif }\end{array}$ & Maju \\
\hline $\mathrm{C}$ & $\begin{array}{l}\text { Industri } \\
\text { Pengolahan/Manufacturing }\end{array}$ & Non Basis & $\begin{array}{l}\text { Tumbuh } \\
\text { lambat }\end{array}$ & $\begin{array}{l}\text { Tidak } \\
\text { Komparatif }\end{array}$ & Mundur \\
\hline $\mathrm{D}$ & Pengadaan Listrik dan Gas & Non Basis & $\begin{array}{l}\text { Tumbuh } \\
\text { cepat }\end{array}$ & Komparatif & Maju \\
\hline $\mathrm{E}$ & $\begin{array}{l}\text { Pengadaan Air, Pengelolaan } \\
\text { Sampah, Limbah dan Daur } \\
\text { Ulang }\end{array}$ & Basis & $\begin{array}{l}\text { Tumbuh } \\
\text { lambat }\end{array}$ & $\begin{array}{l}\text { Tidak } \\
\text { Komparatif }\end{array}$ & Mundur \\
\hline $\mathrm{F}$ & Konstruksi & Non Basis & $\begin{array}{l}\text { Tumbuh } \\
\text { cepat }\end{array}$ & $\begin{array}{l}\text { Tidak } \\
\text { Komparatif }\end{array}$ & Mundur \\
\hline G & $\begin{array}{l}\text { Perdagangan Besar dan } \\
\text { Eceran; Reparasi Mobil dan } \\
\text { Sepeda Motor }\end{array}$ & Non Basis & $\begin{array}{l}\text { Tumbuh } \\
\text { lambat }\end{array}$ & Komparatif & Maju \\
\hline $\mathrm{H}$ & $\begin{array}{l}\text { Transportasi dan } \\
\text { Pergudangan }\end{array}$ & Non Basis & $\begin{array}{l}\text { Tumbuh } \\
\text { lambat }\end{array}$ & $\begin{array}{l}\text { Tidak } \\
\text { Komparatif }\end{array}$ & Mundur \\
\hline I & $\begin{array}{l}\text { Penyediaan Akomodasi dan } \\
\text { Makan Minum }\end{array}$ & Non Basis & $\begin{array}{l}\text { Tumbuh } \\
\text { cepat }\end{array}$ & $\begin{array}{l}\text { Tidak } \\
\text { Komparatif }\end{array}$ & Mundur \\
\hline $\mathrm{J}$ & Informasi dan Komunikasi & Basis & $\begin{array}{l}\text { Tumbuh } \\
\text { cepat }\end{array}$ & Komparatif & Maju \\
\hline $\mathrm{K}$ & Jasa Keuangan dan Asuransi & Non Basis & $\begin{array}{l}\text { Tumbuh } \\
\text { lambat }\end{array}$ & $\begin{array}{l}\text { Tidak } \\
\text { Komparatif }\end{array}$ & Mundur \\
\hline $\mathrm{L}$ & Real Estat & Basis & $\begin{array}{l}\text { Tumbuh } \\
\text { lambat }\end{array}$ & $\begin{array}{l}\text { Tidak } \\
\text { Komparatif }\end{array}$ & Mundur \\
\hline $\mathrm{M}, \mathrm{N}$ & Jasa Perusahaan & Non Basis & $\begin{array}{l}\text { Tumbuh } \\
\text { lambat }\end{array}$ & Komparatif & Maju \\
\hline $\mathrm{O}$ & Administrasi Pemerintahan, & Basis & Tumbuh & Komparatif & Mundur \\
\hline
\end{tabular}




\begin{tabular}{|c|c|c|c|c|c|}
\hline \multirow{2}{*}{ Kategori } & \multirow{2}{*}{$\begin{array}{l}\text { Lapangan Usaha } \\
\text { (Sektor) }\end{array}$} & \multirow{2}{*}{ LQ } & \multicolumn{3}{|c|}{ Shift Share } \\
\hline & & & KPP & KPPW & PS \\
\hline & $\begin{array}{l}\text { Pertahanan dan Jaminan } \\
\text { Sosial }\end{array}$ & & lambat & & \\
\hline $\mathrm{P}$ & Jasa Pendidikan & Basis & $\begin{array}{l}\text { Tumbuh } \\
\text { cepat }\end{array}$ & Komparatif & Maju \\
\hline Q & $\begin{array}{l}\text { Jasa Kesehatan dan Kegiatan } \\
\text { Sosial }\end{array}$ & Basis & $\begin{array}{l}\text { Tumbuh } \\
\text { cepat }\end{array}$ & Komparatif & Maju \\
\hline $\mathrm{R}, \mathrm{S}, \mathrm{T}, \mathrm{U}$ & Jasa lainnya & Basis & $\begin{array}{l}\text { Tumbuh } \\
\text { lambat }\end{array}$ & Komparatif & Mundur \\
\hline
\end{tabular}

Sumber : Hasil Analisis, 2020

\section{Analisis Kependudukan}

Penduduk Kabupaten Kerinci berdasarkan proyeksi penduduk tahun 2018 sebanyak 237.791 jiwa yang terdiri atas 118.656 jiwa penduduk laki-laki dan 119.135 jiwa penduduk perempuan. Dibandingkan dengan proyeksi jumlah penduduk tahun 2015, penduduk Kabupaten Kerinci mengalami pertumbuhan sebesar 1,24 persen. Sementara itu besarnya angka rasio jenis kelamin tahun 2018 penduduk laki-laki terhadap penduduk perempuan sebesar 99,60. Kepadatan penduduk di Kabupaten Kerinci tahun 2018 mencapai 71,45 jiwa $/ \mathrm{km}_{2}$ dengan rata-rata jumlah penduduk per rumah tangga 3 orang. Sebagian besar pekerja di Kabupaten Kerinci pada tahun 2016 masih memilih bekerja di sektor pertanian terutama di sub sektor tanaman pangan. Hal ini karena luasnya lahan pertanian yang terdapat di Provinsi Jambi. Berdasarkan perbandingan tiga sektor utama, pilihan bekerja di sektor pertanian masih mendominasi pasar kerja di Kabupaten Kerinci. Jumlah penduduk di Kabupaten Kerinci mengalami peningkatan pada beberapa tahun terakhir. Peningkatan jumlah penduduk dari tahun 2014-2018 dapat dilihat pada tabel 5 .

Tabel 5. Jumlah Penduduk Kabupaten Kerinci tahun 2014-2018

\begin{tabular}{ccc}
\hline No. & Tahun & $\begin{array}{c}\text { Jumlah Penduduk } \\
\text { (Jiwa) }\end{array}$ \\
\hline 1. & 2014 & 234.003 \\
2. & 2015 & 234.882 \\
3. & 2016 & 235.802 \\
4. & 2017 & 236.782 \\
5. & 2018 & 237.791 \\
\hline
\end{tabular}

Sumber: Hasil olahan data sekunder, 2020.

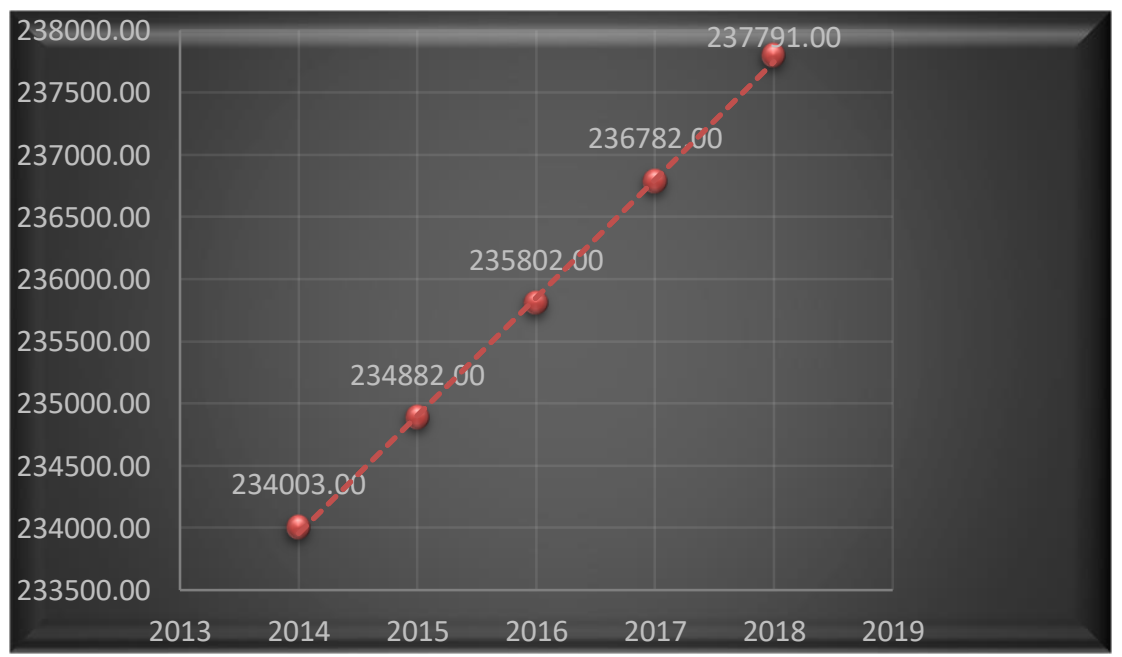

Gambar 3. Kurva Jumlah Penduduk Kabupaten Kerinci tahun 2014-2018 (Sumber : Hasil Analisis, 2020)

Dari kurva pada gambar 3 dapat diketahui bahwa, meski tahun 2014-2018 jumlah penduduk Kabupaten Kerinci mengalami peningkatan, tetapi peningkatan jumlah penduduk tersebut tidak banyak. Jika dikalkulasikan maka rata-rata terjadi peningkatan sebanyak 947 jiwa per tahunnya. 


\section{SIMPULAN}

Hasil penelitian ini menunjukkan bahwa sektor basis yang pertama di Kabupaten Kerinci adalah Sektor Pengadaan Air, Pengelolaan Sampah, Limbah dan Daur Ulang yang mempunyai potensi sangat besar untuk dikembangkan lebih lanjut yaitu dengan nilai LQ sebesar 2.6335. Pertumbuhan sektor ini lambat dan tidak komparatif, oleh sebab itu sektor basis ini mengalami kemunduran. Sektor basis yang kedua di Kabupaten Kerinci ini yaitu Sektor Informasi dan Komunikasi, sektor ini tumbuh lebih cepat, kompratif dan maju. Berdasarkan hasil perhitungan dari kedua alat analisis menunjukkan bahwa yang merupakan sektor basis dan berpotensi untuk dikembangkan sebagai penunjang ekonomi wilayah pada Kabupaten Kerinci dengan kriteria sektor maju dan tumbuh dengan pesat, sektor basis dan kompratif, yaitu Sektor Informasi dan Komunikasi.

\section{DAFTAR PUSTAKA}

Badan Pusat Statistik. (2017). Kabupaten Kerinci dalam Angka 2017. Kabupaten Kerinci

Badan Pusat Statistik. (2018). Provinsi Jambi dalam Angka 2019. Provinsi Jambi.

Badan Pusat Statistik. (2018). Statistik Daerah Kabupaten Kerinci 2018. Kabupaten Kerinci

Badan Pusat Statistik. (2019). Kabupaten Kerinci dalam Angka 2019. Kabupaten Kerinci.

Badan Pusat Statistik. (2019). Produk Domestik Regional Bruto Kabupaten Kerinci Menurut Lapangan Usaha 2014-2018. Kabupaten Kerinci.

Badan Pusat Statistik. (2019). Produk Domestik Regional Bruto Provinsi Jambi Menurut Lapangan Usaha 2014-2018. Provinsi Jambi.

Badan Pusat Statistik. (2019). Provinsi Jambi dalam Angka 2019. Provinsi Jambi.

Darlen, M. F., Hadi, S., \& Ardiansyah, M. (2015). Pengembangan Wilayah Berbasis Potensi Unggulan di Kabupaten Manggarai Timur Provinsi NTT Sebagai Daerah Otonom Baru. Tataloka, 17(1), 3752.

Ernan, R., Sunsun, S., \& Dyah, R. P. (2011). Perencanaan dan. Pengembangan Wilayah. Jakarta: Cresmtpent Press dan Yayasan Pustaka.

Isyanto, A. Y., Sudrajat, S., \& Sujaya, D. H. (2018). Pembangunan Ekonomi Wilayah Kabupaten Ciamis Berbasis Komoditas Peternakan. Mimbar Agribisnis: Jurnal Pemikiran Masyarakat Ilmiah Berwawasan Agribisnis, 4(2), 109-120.

Jumiyanti, K. R. (2018). Analisis Location Quotient dalam Penentuan Sektor Basis dan Non Basis di Kabupaten Gorontalo. Gorontalo Development Review, 1(1), 29-43

Kartikaningdyah, E. (2012). Analisis Location Quotient Dalam Penentuan Produk Unggulan Pada Beberapa Sektor di Kabupaten Lingga Kepulauan Riau. Jurnal Integrasi, 4(1), 31-46.

Kesuma, N. L. A., \& Utama, I. M. S. (2015). Analisis sektor unggulan dan pergeseran pangsa sektorsektor ekonomi Kabupaten Klungkung. Jurnal Ekonomi Kuantitatif Terapan, 8(1), 100-107.

Kurniawan, B. (2016). Analisis Sektor Ekonomi Unggulan Kabupaten Kerinci Provinsi Jambi. Jurnal Ekonomi Islam (Islamic Economics Journal), 4(1), 1-26.

Mujahid, A. S., \& Marsoyo, A. (2019). Perbandingan Nilai Ekonomi Lahan dalam Kasus Konversi Lahan Sawah di Kecamatan Praya Kabupaten Lombok Tengah. Geodika: Jurnal Kajian Ilmu dan Pendidikan Geografi, 3(2), 58-69.

Negara, A. K. K., \& Putri, A. K. (2020). Analisis Sektor Unggulan Kecamatan Toboali dengan Metode Shift Share dan Location Quotient. Equity: Jurnal Ekonomi, 8(1), 24-36.

Setianto, P., \& Susilowati, I. (2014). Komoditas Perkebunan Unggulan yang Berbasis Pada Pengembangan Wilayah Kecamatan di Kabupaten Banjarnegara Provinsi Jawa Tengah. Jurnal Wilayah dan Lingkungan, 2(2), 143-156.

Siska, D., Hadi, S., Firdaus, M., \& Said, S. (2015). Strategi Pengembangan Ekonomi Wilayah Berbasis Agroindustri di Kawasan Andalan Kandangan Kalimantan Selatan. Jurnal Bina Praja: Journal of Home Affairs Governance, 7(2), 99-110.

Undang-undang Nomor 22 Tahun 1999 tentang Pemerintahan Daerah.

Undang-undang Nomor 32 tahun 2004 tentang Pemerintahan Daerah.

Wahyudi, W. W., Priyarsono, D. S., \& Rifin, A. (2014). Perencanaan Pembangunan Ekonomi Wilayah Berbasis Sektor Unggulan, Kasus: Kabupaten Pasaman Pasca Otonomi Daerah. Jurnal Agribisnis Indonesia (Journal of Indonesian Agribusiness), 2(2), 159-176. 